\title{
Ichthyodiversity of Periyar Tiger Reserve, Kerala, India
}

\author{
K.V. Radhakrishnan ${ }^{1}$ \& B. Madhusoodana Kurup ${ }^{2}$
}

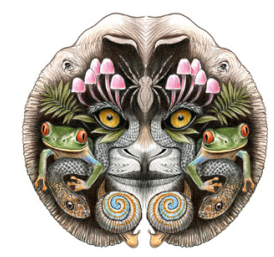

${ }^{1}$ Post Doctoral Research Fellow, Key Laboratory of Ecology and Environment Science in Guangdong Higher Education, Guangdong Provincial Key Laboratory for Healthy and Safe Aquaculture, College of Life Science, South China Normal University, Guangzhou 510631, China

${ }^{2}$ Professor, Fisheries, School of Industrial Fisheries, Cochin University of Science \& Technology, Cochin, Kerala 682016, India Email: ${ }^{1}$ krishnaradh76@gmail.com, ${ }^{2}$ madhukurup@hotmail.com

Date of publication (online): 26 September 2010 Date of publication (print): 26 September 2010 ISSN $0974-7907$ (online) | $0974-7893$ (print)

Editor: Neelesh Dahanukar

\section{Manuscript details:}

Ms \# 02350

Received 20 November 2009

Final received 13 August 2010

Finally accepted 20 August 2010

Citation: Radhakrishnan, K.V. \& B.M. Kurup (2010). Ichthyodiversity of Periyar Tiger Reserve, Kerala, India. Journal of Threatened Taxa 2(10): 1192-1198.

Copyright: (c) K.V. Radhakrishnan \& B Madhusoodana Kurup 2010. Creative Commons Attribution 3.0 Unported License. JoTT allows unrestricted use of this article in any medium for non-profit purposes, reproduction and distribution by providing adequate credit to the authors and the source of publication.

Author Details: Dr. K.V. RADHAKRISHNAN, freshwater fish ecologist, completed his PhD from the School of Industrial Fisheries, Cochin University of Science and Technology, Cochin, Kerala, India. He has a vast knowledge on the taxonomy and ecology of freshwater fishes of Western Ghats of India.

Dr. B. Madhusoodana Kurup is a Professor and Director of School of Industrial Fisheries in Cochin. He is a leading ichthyologist in the country, working on various aspects of fish life history including taxonomy, ecology, population dynamics and also conservation and sustainable utilization of fishery resources.

Author Contribution: KVR involved in field sampling, data analysis and prepared the manuscript. BMK assisted in field sampling and technical guidance in data analysis.

Acknowledgements: The authors are thankful to Director, School of Industrial Fisheries, Cochin University of Science \& Technology, for providing the necessary facilities to carry out the study. The financial assistance from the World Bank aided National Agriculture Technology Indian Council of Agriculture Research Project is gratefully acknowledged. Thanks are also due to C.P. Sunilkumar and M.D. Mahesan, who assisted in sample collection.

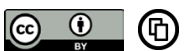

OPEN ACCESS | FREE DOWNLOAD
Abstract: Previous checklists of fishes from the Periyar Tiger Reserve, Kerala merely included species from Periyar Lake and adjoining streams. To fill this lacuna, we conducted a comprehensive survey, across 10 diverse aquatic habitats within Periyar Tiger Reserve, revealing the occurrence of 54 species belonging to six orders and 19 families; an addition of 17 species to the previous lists. Twenty-four species found in this reserve were listed under different threat categories. Forty-six species were found only in less than four sampling sites of which 18 species were encountered in single location each. Nine species were very common, 10 common, 17 moderate, 12 rare and six very rare in their relative abundance. Twenty-two species are endemic to the Western Ghats of which six species are found only in the Periyar Tiger Reserve. The Periyar riverstream system had more number of fish species $(36,67 \%)$ than Pamba river-stream system. Among the different sampling sites, Azhutha had both the highest number of fish species (30) and the highest number of threatened fish species (14). The highest number of low abundant fish species (very rare/rare) was observed at Mlappara (7). Considering the restricted distribution, number of endemic fishes and threat status, it is necessary to implement urgent management plans for the conservation of freshwater fish fauna of Periyar Tiger Reserve.

Keywords: Conservation, distribution, endemism, fish diversity, Periyar Tiger Reserve, spatial variation, threats.

\section{INTRODUCTION}

The Western Ghats of India along with Sri Lanka is considered as one of the biodiversity hotspots of the world (Mittermeier et al. 1998; Myers et al. 2000). The Periyar Tiger Reserve (PTR), one of the biodiversity rich areas in southern Western Ghats from where the Periyar River originates, supports a varied aquatic biota endowed with many endemic and threatened fish species (Silas 1950, 1952; Zacharias et al. 1996; Kurup et al. 2004). Earliest studies on the fish fauna of the PTR dates back to 1948 when Chacko (1948) listed 35 species from the Periyar Lake, including the critically endangered Small Scaled Schizothoracin Lepidopygopsis typus. Later Menon \& Remadevi (1995) described Hypselobarbus kurali from streams adjoining the Periyar Lake while Menon \& Jacob (1996) described Crossocheilus periyarensis and rediscovered the cyprinid, Puntius ophicephalus from Periyar River, raising the total number of fish species to 38. Arun et al. (1996) added six more species to the fish fauna of Periyar Lake, including two exotic fishes, viz. Cyprinus carpio carpio and Oreochromis mossambicus, and four indigenous species, viz. Garra mcclellandi, Bhavania australis, Mesonoemacheilus guentheri and Travancoria jonesi. Additional checklist of species from PTR were prepared by Zacharias et al. (1996) and Arun (1998) who reported 35 and 27 species respectively. Recently Gopi (2001) described anew cyprinid, Garra periyarensis from the upstreams of Periyar, and Kurup \& Radhakrishnan (2005) described a new balitorid, Nemacheilus periyarensis from Periyar Lake.

Majority of studies on fish distribution within PTR have been restricted to the streams of Periyar River and Lake, and have overlooked the species of Pamba River and its main tributary, Azhutha a part of which are located 
inside the boundary of PTR. The present paper provides an updated checklist of the fish fauna of PTR including the Periyar Lake as well as Periyar and Pamba rivers. The paper also provides information on the distribution, relative abundance, threat status and endemism of the various species encountered during the study.

\section{MATERIALS AND METHODS}

\section{Study Area}

The study was undertaken in the Periyar Tiger Reserve $\left(9^{0} 18^{\prime}-9^{\circ} 41^{\prime} \mathrm{N}\right.$ \& $76^{0} 55^{\prime}-77^{0} 25^{\prime} \mathrm{E}$; Fig. 1), which covers an area of $777 \mathrm{~km}^{2}$, of tropical evergreen, semievergreen and moist deciduous forests. The elevation in PTR ranges from 800 to 2019 m with the highest point at Vellimala. The Periyar Lake, which was formed as a result of the construction of the Mullaperiyar Dam, has a total area of $26 \mathrm{~km}^{2}$ and a maximum depth of $46 \mathrm{~m}$ at the highest water level. Along with River Periyar, the River Pamba and its main tributary, Azhutha also drain the Reserve. Ten locations, representing the different aquatic habitats of the entire geographical area of PTR and located at least $5 \mathrm{~km}$ apart were selected for study. These included Pamba (9025.2'N \& 76058.2'E), Azhutha $\left(9^{\circ} 25^{\prime} \mathrm{N} \& 7^{\circ} 4^{\prime} \mathrm{E}\right)$, Pachakkanam $\left(9^{\circ} 27.5^{\prime} \mathrm{N} \& 7^{\circ} 8.4^{\prime} \mathrm{E}\right)$, Vallakkadavu $\left(9^{0} 36.3^{\prime} \mathrm{N} \& 7^{\circ} 4.6^{\prime} \mathrm{E}\right)$, Periyar Lake

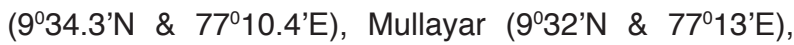
Thannikkudy $\left(9^{\circ} 30^{\prime} \mathrm{N} \& 77^{\circ} 15.4^{\prime} \mathrm{E}\right)$, Ummikuppanthodu $\left(9^{\circ} 28.4^{\prime} \mathrm{N} \& 77^{0} 14.5^{\prime} \mathrm{E}\right)$, Mlappara $\left(9^{0} 28.6^{\prime} \mathrm{N} \& 7^{0} 16.7^{\prime} \mathrm{E}\right)$ and Moolavaigae (9021.4'N \& 77016.3'E).

\section{Fish Sampling}

Sampling was carried out in the selected locations of PTR in three seasons (pre monsoon from February to May, monsoon from June to September and post monsoon from October to January) for a period of two years (May 2004-August 2006). Fishing was carried out, using a variety of gears including cast nets $(16 \mathrm{~mm}$, $18 \mathrm{~mm}, 22 \mathrm{~mm})$, gill nets $(32 \mathrm{~mm}, 38 \mathrm{~mm}, 64 \mathrm{~mm}, 78 \mathrm{~mm}$, $110 \mathrm{~mm})$, drag net $(4 \mathrm{~mm})$, scoop nets and other local contrivances. Visual observations were also carried out if the water was clear, to understand the distribution of fish species. Uniformity in catch per unit effort (number/hour)

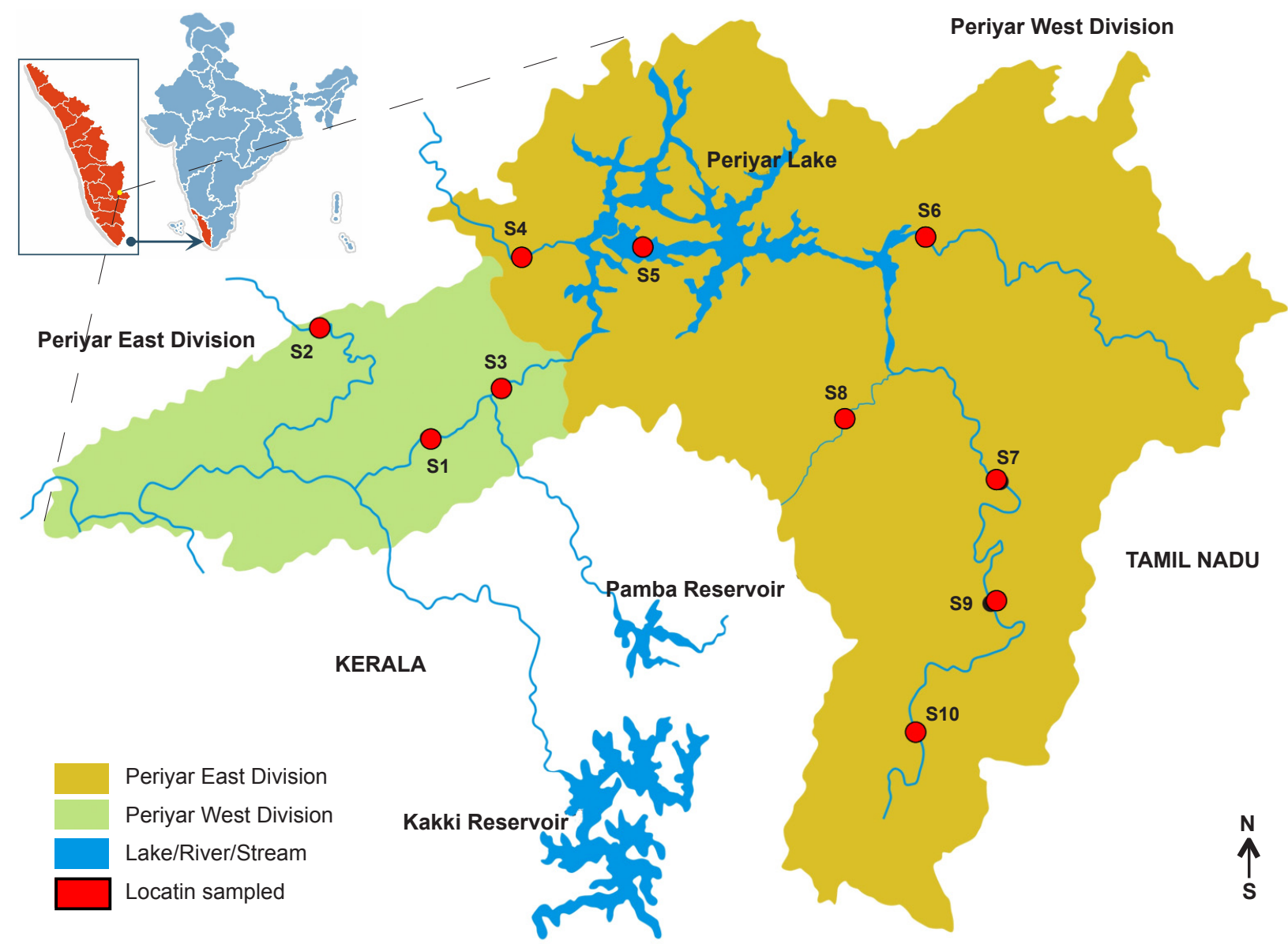

Figure 1. Map of Periyar Tiger Reserve showing the locations sampled for fishes during the period of study. S1 - Pamba; S2 - Azhutha; S3 - Pachakkanam; S4 - Vallakkadavu; S5 - Periyar Lake; S6 - Mullayar; S7 - Thannikkudy; S8 - Ummikuppanthodu; S9 - Mlappara; S10 - Moolavaigae 
was maintained in sampling following Bhat (2003) from which the relative abundance of different species were assigned as very common, common, moderately found, rare and very rare (Thomas et al. 2002). Under the same sampling effort we classify records of 5 or less than 5 individuals of a species as 'very rare', 5-20 as 'rare', 2050 as 'moderate', 50-100 as 'common' and more than 100 as 'very common'. This classification is not based on any standard methodology or literature.

Fishes were identified following Day (1878), Talwar \& Jhingran (1991) and Jayaram (1981, 1999). The threat status of each species was assigned following Dahanukar et al. (2004). The endemism of fish species was determined following Gopalakrishnan \& Ponniah (2000), Gopi (2000) and Shaji et al. (2000).

\section{RESULTS}

\section{Fish fauna and distribution}

A total of 54 fish species belonging to six orders and 19 families were recorded from various study sites. The list of fish species and details of their threat status, relative abundance, endemism and distribution at different sampling sites are given in Table 1. The family Cyprinidae dominated with a numerical strength of 23 species (43\%), followed by Balitoridae with eight (15\%) species. Four exotic species, viz. Oreochromis mossambicus, Cyprinus carpio carpio, Poecilia reticulata and Clarias gariepinus were also recorded.

Puntius fasciatus and Devario aequipinnatus were found distributed in nine study sites. Six species, viz. Hypselobarbus kurali, Tor khudree, Rasbora daniconius, Puntius filamentosus, Garra mullya and Barilius gatensis were found in 5-8 locations. Fourty-six species were observed in less than four locations of which 18 species were encountered only from single locations each. The highest number of fish species were encountered in Azhutha (30,56\%), followed by Pamba (23, 43\%), and Periyar Lake (20, 54\%).

\section{Threat status and relative abundance}

Twenty-four species (45\%) found in PTR were listed as threatened. Lepidopygopsis typus has been listed as Critically Endangered while 13 other species were Endangered and 10 were Vulnerable in their threat status (Fig. 2). Nine (17\%) species were found to be very common, $10(19 \%)$ species were common, 17 (31\%) species were moderately found, $12(22 \%)$ species were rare and $6(11 \%)$ species were very rare in their relative abundance. Species such as Lepidopygopsis typus, Crossocheilus periyarensis, Travancoria jonesi, Nemacheilus periyarensis, Hypselobarbus periyarensis and Puntius denisonii were found to be 'very rare' inside the PTR.

\section{Endemism}

Twenty-two (41\%) species were found to be endemic to the Western Ghats of which six species were strictly endemic to the Periyar Tiger Reserve. These included four species of cyprinids, viz. Hypselobarbus periyarensis, Lepidopygopsis typus, Crossocheilus periyarensis and Garra periyarensis and two species of Balitorids Nemacheilus periyarensis and $N$. menoni. Figure 3 shows nature of endemism of fish species encountered in the PTR.

\section{DISCUSSION}

The present study revealed that the Periyar Lake and the river stream within the PTR harbour rich and diverse fish fauna. Seventeen fish species were found to be new additions to the PTR. This was attributed to the fact that, the field surveys were carried out in the Periyar Lake and its associated streams as well as Pamba River and its main tributary - Azhutha. Nevertheless, the present study also revealed the disappearance of some fish species in recent years from the lake-stream system. Of the 35 fish species reported by Chacko (1948) in Periyar Lake and connected streams, cyprinids such as Puntius melanostigma (currently valid as $P$. mahecola), $P$. arulius,

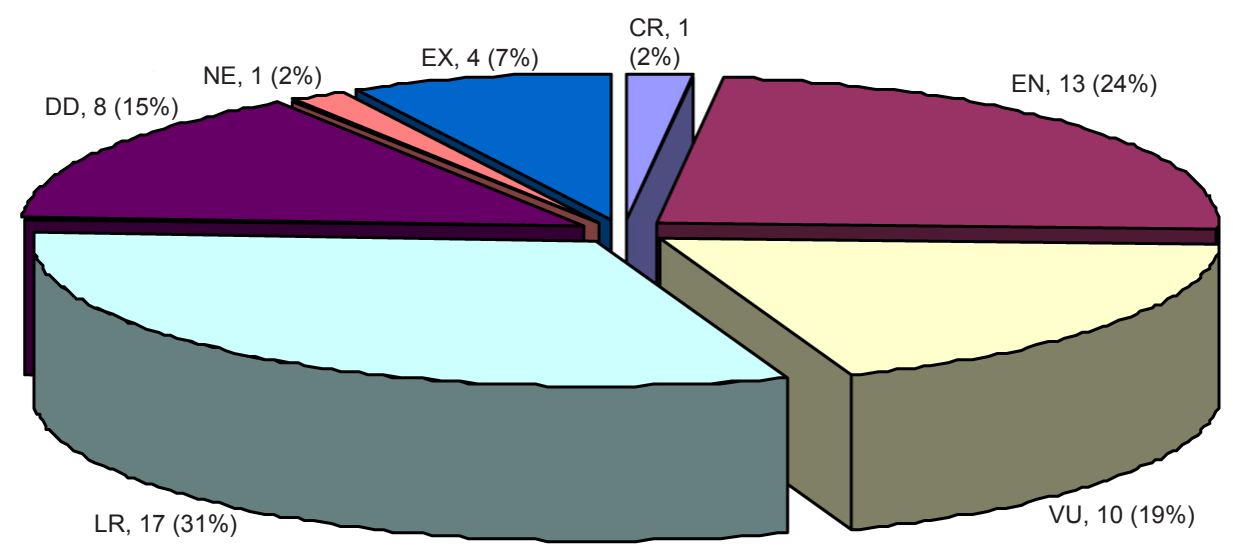

Figure 2. Threat status of fishes collected from Periyar Tiger Reserve. CR - Critically Endangered; EN - Endangered;

VU - Vulnerable; LR - Low Risk; EX - Exotic; DD - Data Deficient; NE - Not Evaluated 
Table 1. List of fishes collected from Periyar Tiger Reserve - their threat status, relative abundance, endemism and distribution at different sampling sites

\begin{tabular}{|c|c|c|c|c|c|c|c|c|c|c|c|c|c|c|}
\hline & Order/Family/Species & $\begin{array}{l}\text { Threat } \\
\text { status }\end{array}$ & $\begin{array}{c}\text { Relative } \\
\text { abundance }\end{array}$ & Endemism & \multicolumn{10}{|c|}{ Distribution in study sites } \\
\hline & & & & & s1 & s2 & s3 & S4 & S5 & s6 & s7 & s8 & s9 & S10 \\
\hline & Order: Anguilliformes & & & & & & & & & & & & & \\
\hline & Family: Anguillidae & & & & & & & & & & & & & \\
\hline \multirow[t]{3}{*}{1} & Anguilla bengalensis bengalensis & EN & rare & EN-IS & & & & & & + & & & & \\
\hline & Order: Cypriniformes & & & & & & & & & & & & & \\
\hline & Family: Cyprinidae & & & & & & & & & & & & & \\
\hline 2 & Cyprinus carpio carpio & EX & very common & WD & & & & & + & & & & & \\
\hline 3 & Tor khudree & Vu & very common & EN-IS & + & + & & & + & + & + & & + & \\
\hline 4 & Hypselobarbus curmuca & EN & moderate & EN-IS & + & + & & & & & & & & \\
\hline 5 & Hypselobarbus kurali & DD & common & EN-K & & & + & & + & + & + & & + & \\
\hline 6 & Hypselobarbus periyarensis & DD & Very rare & EN-PTR & & & & & & & + & & + & \\
\hline 7 & Puntius amphibious & LR & common & EN-IS & + & + & & & + & & & & & \\
\hline 8 & Puntius denisonii & EN & Very rare & EN-WG & & + & & & & & & & & \\
\hline 9 & Puntius fasciatus & EN & very common & EN-WG & + & + & + & + & + & + & + & & + & + \\
\hline 10 & Puntius filamentosus & DD & very common & EN-I & + & + & + & + & + & + & + & & & \\
\hline 11 & Puntius ophicephalus & EN & rare & EN-WG & & & & & & & & + & + & + \\
\hline 12 & Puntius ticto & LR & rare & WD & & + & & & & & & & & \\
\hline 13 & Puntius vittatus & Vu & moderate & EN-IS & + & + & & & & & & & & \\
\hline 14 & Salmophasia boopis & LR & common & EN-WG & + & + & & & & & & & & \\
\hline 15 & Rasbora daniconius & LR & very common & WD & + & + & + & & + & + & + & & & \\
\hline 16 & Barilius bakeri & Vu & common & EN-K & + & + & & & & & & & & \\
\hline 17 & Barilius gatensis & DD & very common & EN-WG & + & + & + & + & + & + & + & & + & \\
\hline 18 & Devario aequipinnatus & LR & very common & WD & + & + & + & + & + & + & + & + & + & \\
\hline 19 & Devario malabaricus & LR & moderate & EN-IS & & & & & + & + & & & & \\
\hline 20 & Lepidopygopsis typus & $C R$ & Very rare & EN-PTR & & & & & & & + & & + & + \\
\hline 21 & Crossocheilus periyarensis & Vu & Very rare & EN-PTR & & & & & & & + & & + & \\
\hline 22 & Garra mullya & LR & very common & EN-IS & + & + & + & & & + & + & & + & + \\
\hline 23 & Garra periyarensis & DD & rare & EN-PTR & & & & & & & + & & + & \\
\hline \multirow[t]{2}{*}{24} & Garra surendranathanii & EN & rare & EN-K & & + & & & & & & & & \\
\hline & Family: Balitoridae & & & & & & & & & & & & & \\
\hline 25 & Bhavania australis & EN & moderate & EN-WG & & & & & & & + & & + & + \\
\hline 26 & Travancoria jonesi & EN & Very rare & EN-K & & & & & & & & & + & \\
\hline 27 & Schistura denisoni & Vu & moderate & EN-I & & & & & & & + & & + & \\
\hline 28 & Mesonoemacheilus guentheri & LR & moderate & EN-K & + & & + & & & & + & & & \\
\hline 29 & Mesonoemacheilus triangularis & LR & moderate & EN-K & + & + & + & & & & & & & \\
\hline 30 & Nemacheilus keralensis & EN & rare & EN-K & & & & & & & & & + & \\
\hline 31 & Nemacheilus menoni & DD & moderate & EN-PTR & & & & & & & + & & + & + \\
\hline \multirow[t]{2}{*}{32} & Nemacheilus periyarensis & $\mathrm{NE}$ & Very rare & EN-PTR & & & & & + & & + & & & \\
\hline & Family: Cobitidae & & & & & & & & & & & & & \\
\hline \multirow[t]{3}{*}{33} & Lepidocephalus thermalis & LR & moderate & EN-IS & & & & & + & & & & & \\
\hline & Order: Siluriformes & & & & & & & & & & & & & \\
\hline & Family: Bagridae & & & & & & & & & & & & & \\
\hline 34 & Batasio travancoria & EN & moderate & EN-WG & + & + & & & & & & & & \\
\hline 35 & Mystus armatus & LR & moderate & EN-IS & & + & & & & & & & & \\
\hline
\end{tabular}




\begin{tabular}{|c|c|c|c|c|c|c|c|c|c|c|c|c|c|c|}
\hline & Order/Family/Species & $\begin{array}{l}\text { Threat } \\
\text { status }\end{array}$ & $\begin{array}{c}\text { Relative } \\
\text { abundance }\end{array}$ & Endemism & \multicolumn{10}{|c|}{ Distribution in study sites } \\
\hline & & & & & s1 & s2 & s3 & S4 & S5 & S6 & S7 & S8 & s9 & s10 \\
\hline & Family: Siluridae & & & & & & & & & & & & & \\
\hline \multirow[t]{2}{*}{36} & Ompok bimaculatus & EN & common & WD & + & & & & + & & + & & & \\
\hline & Family: Sisoridae & & & & & & & & & & & & & \\
\hline \multirow[t]{2}{*}{37} & Glyptothorax annandalei & EN & rare & WD & & & + & & & & & & & \\
\hline & Family: Claridae & & & & & & & & & & & & & \\
\hline 38 & Clarias dussumieri & Vu & moderate & WD & + & + & & & & & & & & \\
\hline \multirow[t]{2}{*}{39} & Clarias gariepinus & EX & rare & WD & & & & & + & & & & & \\
\hline & Family: Heteropneustidae & & & & & & & & & & & & & \\
\hline \multirow[t]{3}{*}{40} & Heteropneustes fossilis & VU & rare & EN-IS & + & + & & & + & & & & & \\
\hline & Order: Beloniformes & & & & & & & & & & & & & \\
\hline & Family: Belonidae & & & & & & & & & & & & & \\
\hline \multirow[t]{3}{*}{41} & Xenentodon cancila & LR & common & WD & + & + & & & & & & & & \\
\hline & Order: Cyprinodontiformes & & & & & & & & & & & & & \\
\hline & Family: Aplocheilidae & & & & & & & & & & & & & \\
\hline \multirow[t]{2}{*}{42} & Aplocheilus lineatus & DD & moderate & EN-IS & & & + & & + & & & & & \\
\hline & Family: Poecilidae & & & & & & & & + & & & & & \\
\hline \multirow[t]{2}{*}{43} & Poecilia reticulata & EX & rare & WD & & & & & & & & & & \\
\hline & Family: Mastacembelidae & & & & & & & & & & & & & \\
\hline \multirow[t]{3}{*}{44} & Mastacembelus armatus & LR & moderate & WD & + & + & & & & & & & & \\
\hline & Order: Perciformes & & & & & & & & & & & & & \\
\hline & Family: Ambassidae & & & & & & & & & & & & & \\
\hline 45 & Parambassis dayi & EN & common & EN-I & + & + & & & + & & & & & \\
\hline \multirow[t]{2}{*}{46} & Parambassis thomassi & VU & moderate & EN-WG & & + & & & & & & & & \\
\hline & Family: Nandidae & & & & & & & & & & & & & \\
\hline \multirow[t]{2}{*}{47} & Pristolepis marginata & VU & moderate & EN-WG & & + & & & + & & & & & \\
\hline & Family: Cichilidae & & & & & & & & & & & & & \\
\hline 48 & Etroplus maculatus & LR & common & EN-IS & & + & & & & & & & & \\
\hline \multirow[t]{2}{*}{49} & Oreochromis mossambicus & EX & very common & WD & & & & & + & & & & & \\
\hline & Family: Gobiidae & & & & & & & & & & & & & \\
\hline \multirow[t]{2}{*}{50} & Glossogobius giuris & LR & common & WD & + & + & & & & & & & & \\
\hline & Family: Anabantidae & & & & & & & & & & & & & \\
\hline \multirow[t]{2}{*}{51} & Anabas testudineus & Vu & moderate & WD & + & + & & & & & & & & \\
\hline & Family: Channidae & & & & & & & & & & & & & \\
\hline 52 & Channa gachua & $\mathrm{DD}$ & rare & WD & & & & & & + & & & & \\
\hline 53 & Channa marulius & LR & rare & WD & & + & & & & & & & & \\
\hline 54 & Channa striata & LR & common & WD & & + & & & & & & & & \\
\hline
\end{tabular}

CR - Critically Endangered; EN - Endangered; VU - Vulnerable; LR - Low Risk; EX - Exotic; DD - Data Deficient; NE - Not Evaluated; WD - Widely Distributed; EN-IS - Endemic to Indian Subcontinent; EN-I - Endemic to India; EN-WG - Endemic to Western Ghats; EN-K - Endemic to Kerala; EN-PTR - Endemic to Periyar Tiger Reserve. Sample sites S1 to S10 as per Figure 1.

$P$. pinnauratus ( $P$. sarana), Barilius bendelisis and Garra lampta; catfish species, Mystus vittatus and the feather back Nototpterus notopterus could not be collected during the present study. Arun (1998) also had a similar observation of not recording 16 species from the list of Chacko (1948). Zacharias et al. (1996) reported 35 fish species representing 11 families and 21 genera, of which Nemacheilus botia (Acanthocobitis botia), N. evezardi (Indoreonectes evezardi), Barilus bendelisis and Garra gotyla stenorhynchus were not represented in our study. Garra mcclellandi, which was reported from Periyar Lake and streams (Easa \& Shaji 1997), was also not 


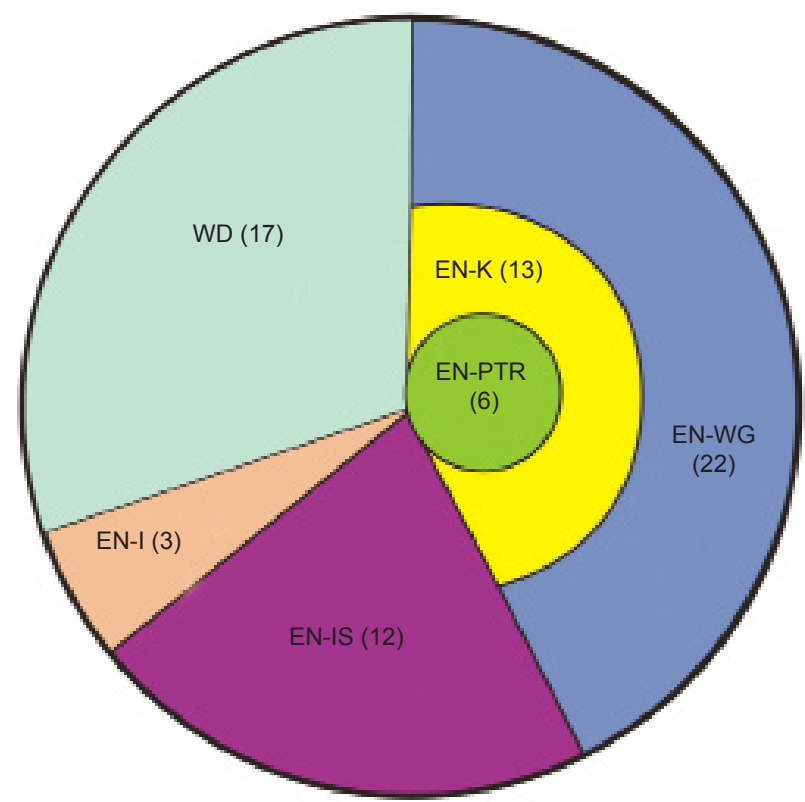

Figure 3. Endemism of fishes collected from Periyar Tiger Reserve.

WD - Widely Distributed; EN-IS - Endemic to Indian

Subcontinent; EN- I - Endemic to India; EN-WG - Endemic to Western Ghats; EN-K - Endemic to Kerala; EN-PTR - Endemic to Periyar Tiger Reserve

encountered in the present study while, G. periyarensis which shows great similarity in body morpho-meristics with G. mcclellandi was collected in adequate numbers. The present collection included all the 27 fishes recorded by Arun (1998) from the Periyar Lake and stream systems.

Majority (45\%) of the fish fauna of PTR is threatened. Ten species of Cyprinids are threatened of which Lepidopygopsis typus is listed as Critically Endangered and another five species categorised as Endangered. Among other families, four out of eight balitorids and nine out of 21 species in all other families are threatened. The high rate of endemism of fish fauna in PTR, one of the richest biodiversity areas in Western Ghats is evident from the present study. Restricted distribution of fishes in PTR was also mentioned by Zacharias et al. (1996) and Arun (1999) who reported 13 (37\%) and 14 (52\%) species of their fish collection from PTR as endemic to Western Ghats. Large number of threatened fishes coupled with high rate of endemism emphasizes the importance of this bio-reserve with respect to fish fauna and points at the necessity of stringent protection measures for conserving its unique fish germplasm.

Thirty-six (67\%) fish species were found restricted to Periyar lake-stream systems of which Lepidocephalus thermalis and all the four exotic fishes were found only in Periyar Lake. Ten species, viz., Lepidopygopsis typus, Puntius ophicephalus, Crossocheilus periyarensis, Hypselobarbus periyarensis, Garra periyarensis, Bhavania australis, Travancoria jonesi, Nemacheilus menoni, N. keralensis and Schistuara denisoni were observed only from upstream locations of Periyar River such as Thannikkudy, Ummikuppanthodu, Mlappara and Moolavaigae. Except Bhavania australis, all these species were low in abundance (rare/very rare) and except Garra periyarensis, all the species of this group were listed as threatened. Of the different species found restricted to Pamba and Azhutha streams, eight species, including endangered and rare Puntius denisonii and Garra surendranathanii, were found only in Azhutha Stream. Fifteen species (28\%) were found distributed both in Periyar and Pamba river-stream systems which included Tor khudree, Puntius fasciatus, Ompok bimaculatus and Parambassis dayi. Besides high diversity, Azhutha also had the highest number (14) of threatened fish species observed in any location, followed by Pamba (11) and Mlappara (10). The highest number of low abundant species was observed in Mlappara (7). Azhutha and Thannkkudy had five fish species each and Periyar Lake had four species under low abundant category. The locations with highest number of threatened and low abundant fishes deserve more attention for conservation and so may be prioritised as aquatic sanctuaries or special protection zones in the management plans for conserving fish diversity of PTR.

\section{CONCLUSION}

The present study illustrates the status of PTR, as one of the richest areas of fish diversity and endemism within the Western Ghats Hotspot. The presence of a number of endemic and threatened fish species necessitates proper conservation and management actions to be developed and implemented in PTR.

\section{REFERENCES}

Arun, L.K. (1998). Status and distribution of fishes in Periyar lake-stream system of southern Western Ghats, pp. 77-87. In: Fish Genetics and Biodiversity Conservation. National Bureau of Fish Genetic Resources publications, Nature conservators, Muzaffarnagar, 492pp.

Arun, L.K. (1999). Patterns and Processes of Fish Assemblage in Periyar Lake - valley system of Southern Western Ghats. KFRI Research Report, Kerala Forest Research Institute, Peechi, Kerala, 142pp.

Arun, L.K., C.P. Shaji \& P.S. Easa (1996). Record of new fishes from Periyar Tiger Reserve. Journal of the Bombay Natural History Society 93: 103-104.

Bhat, A. (2003). Diversity and composition of freshwater fishes in streams of Central Western Ghats, India. Environmental Biology of Fishes 68: 25-38.

Chacko, P.I. (1948). Development of fisheries of the Periyar Lake. Journal of the Bombay Natural History Society 48: 191-192.

Dahanukar, N., R. Raut \& A. Bhat (2004). Distribution, endemism and threat status of freshwater fishes in the Western Ghats of India. Journal of Biogeography 31: 123-136.

Day, F. (1878). The fishes of India; Being a natural history of the 
fishes known to inhabit the seas and fresh waters of India, Burma and Ceylon. William Dawson \& Sons Ltd., London, $\mathrm{xx}+778 \mathrm{pp}, 196 \mathrm{pls}$.

Easa, P.S. \& C.P. Shaji (1997). Freshwater fish diversity in Kerala part of Nilgiri Biosphere Reserve. Current Science 73: $180-182$.

Gopalakrishnan, A. \& A.G. Ponniah (2000). An overview of endemic fish diversity of Western Ghats, pp. 1-12. In: Ponniah, A.G. \& A. Gopalakrishnan (eds.). Endemic Fish Diversity of Western Ghats. NBFGR-NATP publication, National Bureau of Fish Genetic Resources, Lucknow, India, 347pp.

Gopi, K.C. (2000). Freshwater Fishes of Kerala State, pp. 5676. In: Ponniah, A.G. \& A. Gopalakrishnan (eds.). Endemic Fish Diversity of Western Ghats. NBFGR-NATP publication, National Bureau of Fish Genetic Resources, Lucknow, India, $347 p p$.

Gopi, K.C. (2001). Garra periyarensis - a new cyprinid fish from Periyar Tiger Reserve, Kerala, India. Journal of the Bombay Natural History Society 98: 82-83.

Jayaram, K.C. (1981). Freshwater Fishes of India - A Handbook. Zoological survey of India, Calcutta, 482pp.

Jayaram, K.C. (1999). The Freshwater Fishes of The Indian Region. Narendra Publishing House, New Delhi, xxvii+ $551 \mathrm{pp}$.

Kurup, B.M. \& K.V. Radhakrishnan (2005). Fishes of the genus Nemacheilus (Bleeker, 1863) in Kerala with description of a new species, Nemacheilus periyarensis. Journal of the Bombay Natural History Society 102: 75-78.

Kurup, B.M., K.V. Radhakrishnan \& T.G. Manojkumar (2004). Biodiversity status of fishes inhabiting rivers of Kerala (S India) with special reference to endemism, threats and conservation measures, pp. 163-182. In: Wellcome, R.L. \& T. Petr (eds.). Proceedings of LARS2., 2nd large rivers symposium. Phnom Penh. 11 ${ }^{\text {th }}$ to $14^{\text {th }}$ February 2003.
Menon, A.G.K. \& P.C. Jacob (1996). Crossocheilus periyarensis, a new cyprinid fish from Thannikudy (Thekkady), Kerala, India. Journal of the Bombay Natural History Society 93: 6264.

Menon, A.G.K. \& K. Remadevi (1995). Hypselobarbus kurali (Pisces: Cyprinidae) a new large barb from the south western rivers of peninsular India. Journal of the Bombay Natural History Society 92: 389-393.

Mittermeier, R.A., N. Myers, J.B. Thomsen, G.A.B. Da Fonseka \& S. Oliveri (1998). Biodiversity hotspots and major tropical wilderness areas: Approaches to setting conservation priorities. Conservation Biology 3: 516-520.

Myers, N., R.A. Mittermeier, C.G. Mittermeier, G.A.B. Da Fonseka \& J. Kents (2000). Biodiversity hotspots for conservation priorities. Nature 403: 853-858.

Shaji, C. P., P. S. Easa \& A. Gopalakrishnan (2000). Freshwater fish diversity of Western Ghats, pp. 35-35. In: Ponniah, A.G. \& A. Gopalakrishnan (eds.). Endemic Fish Diversity of Western Ghats. NBFGR-NATP publication, National Bureau of Fish Genetic Resources, Lucknow, India, 347pp.

Silas, E.G. (1950). On a collection fish from Travancore. Journal of the Bombay Natural History Society 48: 792-797.

Silas, E.G. (1952). Fishes from the high range of Travancore. Journal of the Bombay Natural History Society 50: 232-330.

Talwar, P.K. \& V.G. Jhingran (1991). Inland Fishes of India and Adjacent Countries - Vol. 1 \& 2. Oxford and IBH Publishing Company, New Delhi, 1158pp.

Thomas, R., M.J. George \& C.R. Biju (2002). Freshwater fishes of southern Kerala with notes on the distribution of endemic and endangered species. Journal of the Bombay Natural History Society 99: 47-52.

Zacharias, V.J., A.K. Bhardwaj \& P.C. Jacob (1996). Fish fauna of Periyar Tiger Reserve. Journal of the Bombay Natural History Society 93: 38-43. 